\title{
Editorial
}

\section{0 impacto da complexidade tributária e dos parcelamentos especiais na tomada de decisão da (des)obediência tributária das empresas brasileiras listadas na b3: um estudo sob a ótica da teoria dos jogos}

\author{
Antônio Paulo Machado Gomes \\ apmg.machado@gmail.com \\ Doutor em Controladoria e Contabilidade pela Universidade Federal de Minas Gerais (FACE/UFMG) \\ Professor no Departamento de Contabilidade da Faculdade IBMEC.
}

\begin{abstract}
Em sua obra "Riqueza das Nações, de 1776", Adam Smith (1985) esclarece que um sistema tributário eficiente deve ser neutro, justo e simples. Neutro, porque os tributos não podem afetar a economia, desincentivando-a ou desiquilibrando a concorrência natural do mercado. Justo, porque todos devem pagar os tributos de acordo com a sua capacidade contributiva, ou seja, deve ser equitativo. E simples, porque os contribuintes não podem ter dúvidas em seus recolhimentos. Nas palavras de Smith (1985, p. 248), "a data do recolhimento, a forma de recolhimento e a soma a pagar devem ser claras e evidentes para o contribuinte e para qualquer outra pessoa". Para o autor, a complexidade da tributação estimula ao não pagamento dos tributos devidos.

Na contramão do defendido por Adam Smith, o Brasil é reconhecidamente um país de elevada complexidade tributária. Conforme o Instituto Brasileiro de Planejamento e Tributação (IBPT, 2019), considerando-se apenas a Legislação Tributária, são 390.726 orientações publicadas desde a Constituição de 1988. É em função dessa quantidade enorme de leis que o estudo internacional de Hoppe, Schanz, Sturm \& Sureth-Sloane (2021) classificou o Brasil como o país de maior complexidade tributária dentre 190 países analisados. Segundo os autores, o Brasil é o único país que a complexidade tributária está presente tanto no seu sistema tributário como no regulamento do seu imposto de renda.

A partir dessa perspectiva é que foi desenvolvida a tese de que a complexidade tributária somada aos parcelamentos especiais incentiva a desobediência tributária. Apesar de parecer um senso comum que a complexidade tributária impacta a desobediência tributária, conforme explicitado por Cunha (2007), nenhum conhecimento científico pode ser considerado óbvio ou imune de sustentação científica. Logo, a tese buscou demonstrar cientificamente que a complexidade tributária e os parcelamentos especiais são variáveis que influenciam a probabilidade de uma empresa tornar-se desobediente da legislação tributária.

Aqui, cabe-se definir o conceito de desobediência tributária aplicada na tese, sendo que, conforme Hanlon e Heitzman (2010), a desobediência tributária ocorre quando os contribuintes não cumprem com a lei fiscal, sendo que ela pode ocorrer por dois caminhos, quais sejam, de forma involuntária, quando os contribuintes não conseguem interpretar corretamente a lei tributária, ou de forma voluntária, através da evasão ou elisão fiscal. Ambos os caminhos são prejudiciais à sociedade, pois terão uma restrição dos valores a serem arrecadados dos tributos e, consequentemente, faltará recursos para aplicação em educação, saúde, segurança e bem-estar social. Além disso, parte dos tributos serão aplicados em recursos que não geram benefícios para sociedade como resolução de conflitos entre contribuintes e fiscalização que só aumentam a desconfiança entre esse par.

Já a complexidade tributária é dita como sendo a dificuldade que o contribuinte tem para cumprir suas responsabilidades fiscais e entender as suas respectivas obrigações tributárias, conforme o Office of Tax Simplification (OTS, 2015), um órgão que estuda a simplificação tributária no Reino Unido. Já o parcelamento especial é definido como "uma oferta por tempo limitado do governo a um grupo específico de contribuintes para que eles paguem seus tributos inadimplidos relacionados a um(ns) período(s) tributário(s) anterior(es), em troca da redução dos juros e das multas, bem como a não aplicação da lei penal (Baer e LeBorgne, 2008, p. 5).

Para verificar o relacionamento entre complexidade tributária, parcelamentos especiais e desobediência tributária, primeiro a tese desenvolveu um modelo teórico, baseado na teoria dos jogos, no qual foi exposto todas as fases de um processo administrativo fiscal, sendo identificado as principais decisões estratégicas dos contribuintes e da fiscalização federal, bem como as suas recompensas por cada decisão estratégica. Segundo a teoria dos jogos um jogo pode ser resolvido escolhendo as melhores decisões estratégicas. No caso do modelo desenvolvido, verificou-se que a melhor decisão estratégica do contribuinte é desobedecer a legislação tributária, e caso seja fiscalizado e autuado, deve-se recorrer e impugnar o auto de infração, e se esse for mantido, recolher o débito tributário em um parcelamento especial. Baseado nessa decisão estratégica do contribuinte, a melhor decisão estratégica da fiscalização é fiscalizar e autuar o contribuinte. Destaca-se que as probabilidades identificadas na tese corroboram os achados do modelo teórico.
\end{abstract}


Além do desenvolvimento do modelo teórico, a tese verificou empiricamente, através de um modelo logit, se as conclusões identificadas eram vistas na sociedade. Para tanto, colheu-se todas as decisões envolvendo as empresas listadas na B3 no âmbito do Conselho Administrativo de Recursos Fiscais (CARF) referentes aos tributos Imposto de Renda (IRPJ), Contribuição Social (CSLL), PIS e COFINS. Como resultado verificou-se que de fato a complexidade tributária e os parcelamentos especiais afetam a probabilidade de uma empresa tornar-se desobediente tributária. O modelo mostrou que quanto maior a complexidade tributária da empresa, maior será as chances dessa empresa envolver-se com uma desobediência tributária. Logo, a tese recomenda que deve-se evitar a complexidade tributária e os parcelamentos especiais.

\section{REFERÊNCIAS BIBLIOGRÁFICA}

Baer, K., \& Le Borgne, E. (2008). Tax amnesties: Theory, trends, and some alternatives. International Monetary Fund.

Cunha, J. D. (2007). Doutores em ciências contábeis da FEA-USP: análise sob a óptica da teoria do capital humano. 2007. Tese de doutorado, Faculdade de Economia, Administração e Contabilidade da Universidade de São Paulo, São Paulo, Brasil.

Hanlon, M., \& Heitzman, S. (2010). A review of tax research. Journal of Accounting and Economics, 50(2-3), 127-178. doi: https://doi.org/10.1016/j.jacceco.2010.09.002

Hoppe, T., Schanz, D., Sturm, S., \& Sureth-Sloane, C. (2018). What are the Drivers of Tax Complexity for MNCs? Global Evidence. Intertax, 46(8/9), 654-675.

Instituto Brasileiro de Planejamento e Tributação (IBPT) (2019, Agosto 15). Oportunidade para o fim da complexidade tributária. Recuperado em 15 agosto, 2019, de https://ibpt.com.br/noticia/2788/Oportunidade-para-o-fim-da-complexidade-tributaria

Office of Tax Simplification (OTS). (2015). Complexity Index, Recuperado em 26 setembro, 2019, de https://www.gov.uk/government/publications/office-of-tax-simplification-complexity-index

Smith, A. (1985). A riqueza das nações: investigação sobre sua natureza e suas causas. Tradução de Luiz João Baraúna ( $2^{\mathrm{a}}$ edição). São Paulo. Nova cultural. 